\title{
PERBEDAAN PENGARUH BACK MASSAGE DAN WOOLWICH MASSAGE TERHADAP PENGELUARAN AIR SUSU IBU
}

\author{
Nur Asmita Rahma Nasution ${ }^{1}$, Oswati Hasanah ${ }^{2}$, Rismadefi Woferst ${ }^{3}$ \\ FKp Universitas Riau ${ }^{1}$, FKp Universitas Riau ${ }^{2}$, FKp Universitas Riau ${ }^{3}$ \\ Fakultas Keperawatan Universitas Riau Jalan Pattimura No 9 Gedung G Pekanbaru Riau \\ Kode Pos 28131 Indonesia \\ Email: mitharahma11@gmail.com
}

\begin{abstract}
Abstrak
Pengeluaran ASI yang tidak lancar bisa menghambat proses menyusui. Beberapa cara yang dapat digunakan sebagai terapi non farmakologis untuk melancarkan pengeluaran ASI adalah dengan memberikan back massage dan woolwich massage karena pemijatan tersebut dapat merangsang pengeluaran hormon oksitosin dan hormon prolaktin. Tujuan dari penelitian ini adalah untuk mengetahui perbedaan pengaruh back massage dan woolwich massage terhadap pengeluaran ASI. Penelitian ini dilakukan di wilayah kerja Puskesmas Harapan Raya Pekanbaru menggunakan metode Quasy Experiment dengan rancangan pre and post test without control group. Sampel dalam penelitian ini diambil menggunakan teknik purposive sampling yaitu ibu postpartum yang menyusui bayi usia 2-8 minggu. Jumlah sampel penelitian sebanyak 34 responden dibagi menjadi 17 responden untuk kelompok back massage dan 17 responden untuk kelompok woolwich massage. Kelompok back massage maupun kelompok woolwich massage diberikan massage selama 15 menit dan dilakukan 3 sesi dalam seminggu. Alat ukur pengeluaran ASI menggunakan indikator pengeluaran ASI pada lembar observasi. Hasil analisis univariat didapatkan 91,2\% responden berusia 20-35 tahun, 55,9\% responden berada pada tingkat pendidikan SMA, dan 52,9\% responden tidak bekerja. Berdasarkan analisis lebih lanjut menggunakan uji Wilcoxon dan uji Mann-Whitney didapatkan ada perbedaan pengaruh yang signifikan antara back massage dan woolwich massage terhadap pengeluaran air susu ibu dengan $p$ value $0,013<\alpha(0,05)$ dimana back massage lebih besar pengaruhnya daripada woolwich massage terhadap pengeluaran ASI $(2,00)$. Back massage and woolwich massage dianjurkan untuk digunakan dalam mengatasi masalah pengeluaran ASI.
\end{abstract}

Kata kunci: Pengeluaran ASI , Back massage, Woolwich massage

\begin{abstract}
Insufficiency of breastmilk ejection can inhibit the breastfeeding process. Back massage and woolwich massage can used as non pharmachology therapy to increase breastmilk ejection because these two technique can release oxytocin and prolactin. This study aims to know the differences in effect of back massage and woolwich massage on breastmilk ejection. This study was conducted in the Harapan Raya Community Health Center in Pekanbaru by using quasy experiment, with pre and post test without control group design. The sample of this study used 34 respondents devided into 17 respondents for the back massage group and 17 respondents for the woolwich massage group, taken with purposive sampling technique. The criteria of respondent on this study is postpartum mothers who breastfed 2 until 8 weeks old infants. The back massage group and the woolwich massage group gave along 15 minutes and carried out for 3 session in a week. Measuring equipment in this study used the indicator of breastmilk ejection on the observation sheet. Univariate analysis showed 91,2\% respondent are 20-35 years old, 55,9\% respondent are high school graduated, and 52,9\% respondent are not work. Further analysis by using Wilcoxon and MannWhitney test showed that there was a significant difference in effect between back massage and woolwich massage on breastmilk ejection and back massage gave a greater effect than woolwich massage on breastmilk ejection (2,00 point). Back massage and woolwich massage are recommended to be used for dealing breastmilk ejection problems.
\end{abstract}

Keywords: Breastmilk ejection, Back massage, Woolwich massage 
Nur Asmita Rahma Nasution', Oswati Hasanah ${ }^{2}$, Rismadefi Woferst ${ }^{3}$, Perbedaan Pengaruh Back Massage Dan Woolwich Massage Terhadap Pengeluaran Air Susu Ibu

\section{PENDAHULUAN}

Air Susu Ibu (ASI) merupakan cairan putih yang dihasilkan kelenjar payudara ibu melalui proses menyusui dan termasuk makanan terbaik bagi bayi (Khasanah, 2011). Menurut Cunningham (2016), ASI merupakan makanan yang ideal untuk neonatus.

Para ahli mengungkapkan bahwa manfaat ASI akan sangat meningkat bila bayi diberikan ASI saja selama 6 bulan pertama kehidupannya (Suherni, 2009). Pemberian ASI eksklusif selama 6 bulan sangat bermanfaat bagi bayi maupun bagi ibu. Oleh karena itu, pemberian ASI saja (ASI eksklusif) sangat direkomendasikan (Soenarwo, 2012).

Data Kementrian Kesehatan Republik Indonesia (2018) menunjukkan persentase bayi yang mendapat ASI eksklusif sampai 6 bulan di Provinsi Riau pada tahun 2017 adalah 57,65\% dan berdasarkan data yang diperoleh dari Dinas Kesehatan Kota Pekanbaru persentase cakupan ASI eksklusif di Kota Pekanbaru pada tahun 2016 adalah 50,67\% dan menurun menjadi 43,90\% pada tahun 2017. Angka tersebut masih tetap rendah dari target pencapaian ASI eksklusif yaitu sebesar $80 \%$.

Menurut Indiarti (2015), produksi ASI erat kaitannya dengan kejiwaan ibu. Keadaan psikologis ibu yang tidak baik akan menurunkan volume ASI dan produksi ASI karena proses menyusui tidak berjalan dengan baik.

Pada saat proses menyusui, akan terjadi pelepasan hormon prolaktin untuk menyebabkan peningkatan sekresi ASI dan hormon oksitosin yang menyebabkan pengeluaran ASI. Hormon ini dirangsang oleh refleks neuroendokrin, yaitu refleks prolaktin dan refleks oksitosin yang dipicu oleh penghisapan puting payudara oleh bayi (Sherwood, 2012).

Cara atau metode lain yang dapat digunakan untuk merangsang refleks prolaktin dan refleks oksitosin selain dengan hisapan bayi yaitu dengan metode tradisional seperti back massage dan woolwich massage yang dapat merangsang produksi dan pengeluaran ASI. Hal ini didukung oleh penelitian Safitri, Susilaningsih, dan Panggayuh (2015) yang menyebutkan back massage dapat memicu stimulasi oksitosin untuk merangsang pengeluaran ASI serta didukung oleh penelitian Sukriana, Dewi, dan Utami (2018) yang menyebutkan bahwa woolwich massage dapat meningkatkan produksi ASI.

\section{Back massage (pijat punggung)} merupakan proses pemijatan pada tulang belakang costa (tulang rusuk) ke 5-6 hingga ke scapula (tulang belikat) (Isnaini \& Diyanti, 2015). Menurut Ward, Clarke, \& Linden (2009), hipotalamus merangsang stimulasi saraf untuk mengekskresikan oksitosin ke dalam darah pada interval waktu sepuluh sampai dua puluh menit setelah mendapat rangsangan. Hal ini didukung oleh hasil penelitian Wahyuni, Hasanah, dan Dewi (2018) yang mengatakan bahwa terdapat pengaruh swedish back massage selama 15 menit per hari terhadap 
Jurnal Ners Indonesia, Vol. 12, No. 1, September 2021

pengeluaran ASI. Berdasarkan hasil penelitian lain oleh Safitri, Susilaningsih, dan Panggayuh (2015) juga didapatkan hasil bahwa perlakuan back massage berpengaruh secara signifikan terhadap pengeluaran ASI.

Produksi dan pengeluaran ASI dapat pula dirangsang dengan melakukan woolwich massage. Menurut Pamuji, Supriyana, Sri, dan Suhartono (2014), massage yang diberikan pada area sinus laktiferus tepatnya $1-1,5 \mathrm{~cm}$ di atas areola mamae ini akan merangsang saraf vegetative dan jaringan bawah kulit sehingga aliran ASI akan menjadi lancar dan memicu rangsangan sel-sel mioepitel yang terdapat di sekitar kelenjar payudara untuk memproduksi hormon prolaktin. Berdasarkan hasil penelitian Barokah dan Faradila (2017), didapatkan hasil bahwa pemberian woolwich massage 15 menit selama 3 hari memengaruhi produksi ASI. Hasil penelitian ini didukung oleh penelitian Sukriana, Dewi, dan Utami (2018) yang mendapatkan hasil bahwa woolwich massage yang dilakukan 15 menit per hari selama 3 hari efektif terhadap produksi ASI ibu postpartum.

Hasil dari data yang diperoleh di Dinas Kesehatan Kota Pekanbaru, cakupan pemberian ASI eksklusif pada tahun 2017 yang tergolong rendah di Kota Pekanbaru berada pada daerah Puskesmas Harapan Raya yaitu 50,52\% dan daerah ini memiliki jumlah ibu hamil terbanyak pada tahun 2017 yaitu sebanyak 2.682. Sedangkan, pada tahun 2018 Puskesmas Harapan Raya Pekanbaru memiliki jumlah ibu hamil sebanyak 1.428. Setelah dilakukan wawancara di wilayah kerja Puskesmas Harapan Raya, didapatkan hasil terdapat 15 orang ibu yang memiliki anak berusia 0-6 bulan. Hasilnya empat ibu mengatakan memberikan ASI eksklusif selama 6 bulan, sebelas ibu mengatakan pernah menyusui ASI tapi tidak eksklusif sekaligus dibantu susu formula. Alasan tujuh dari sebelas ibu yang memberikan susu formula adalah dikarenakan pengeluaran ASI yang sedikit dan empat ibu karena putting yang lecet.

Tujuan penelitian ini adalah mengetahui perbedaan pengaruh back massage dan woolwich massage terhadap pengeluaran ASI. Hasil penelitian diharapkan dapat menjadikan back massage dan woolwich massage sebagai terapi yang dapat mengatasi pengeluaran ASI yang tidak lancar.

\section{METODE PENELITIAN}

Penelitian dilakukan di wilayah kerja Puskesmas Harapan Raya Pekanbaru dengan menggunakan metode Quasi Experiment. Rancangan penelitian yaitu pre and post test without control group yaitu rancangan yang melakukan perlakuan pada kelompok eksperimen, tanpa kelompok kontrol (Dharma, 2015).

Pengambilan sampel penelitian ini menggunakan teknik purposive sampling dengan kriteria inklusinya yaitu Ibu postpartum yang berdomisili di wilayah kerja Puskesmas Harapan Raya, bersedia menjadi responden penelitian, ibu postpartum bayi usia 
Nur Asmita Rahma Nasution', Oswati Hasanah ${ }^{2}$, Rismadefi Woferst ${ }^{3}$, Perbedaan Pengaruh Back Massage Dan Woolwich Massage Terhadap Pengeluaran Air Susu Ibu

2-8 minggu dan masih menyusui ASI eksklusif dikarenakan pada usia ini kerja hormon prolaktin aktif, serta tidak mengonsumsi jamu atau suplemen pelancar ASI. Kriteria eksklusinya yaitu ibu yang tidak bersedia menjadi responden dan yang mengundurkan diri menjadi responden. Jumlah sampel dalam penelitian sebanyak 34 responden, dengan rincian 17 orang responden untuk diberikan perlakuan back massage dan 17 responden lainnya untuk diberikan perlakuan woolwich massage.

Alat ukur yang digunakan yaitu menggunakan lembar observasi berupa indikator pengeluaran ASI dan diukur melalui indikator tersebut. Peneliti mengambil data dengan dibantu asisten penelitian. Analisis data yang digunakan adalah analisis univariat guna menjelaskan data demografi responden tentang usia, pendidikan, dan status pekerjaan serta gambaran dari variabel yaitu pengeluaran ASI pada ibu sebelum dan sesudah dilakukan back massage dan woolwich massage serta analisis bivariat untuk melihat perbedaan pengaruh back massage dan woolwich massage terhadap pengeluaran ASI menggunakan uji alternatif Wilcoxon dan Mann-Whitney.

\section{HASIL PENELITIAN}

\section{Analisis Univariat}

Distribusi karakteristik responden digambarkan sebagai berikut:
Tabel 1

Gambaran Distribusi Karakteristik Responden

\begin{tabular}{|c|c|c|c|c|c|c|}
\hline \multirow{5}{*}{ Karakteristik } & \multirow{2}{*}{\multicolumn{2}{|c|}{$\begin{array}{c}\text { Kelompok } \\
\text { Back }\end{array}$}} & \multirow{2}{*}{\multicolumn{2}{|c|}{$\begin{array}{l}\text { Kelompok } \\
\text { Woolwich }\end{array}$}} & \multicolumn{2}{|c|}{ Jumlah } \\
\hline & & & & & \multirow[b]{4}{*}{$\mathbf{N}$} & \multirow[b]{4}{*}{$\%$} \\
\hline & \multirow{2}{*}{\multicolumn{2}{|c|}{$\begin{array}{c}\text { Massage } \\
(\mathrm{n}=17)\end{array}$}} & \multirow{2}{*}{\multicolumn{2}{|c|}{$\begin{array}{c}\text { Massage } \\
(\mathrm{n}=17)\end{array}$}} & & \\
\hline & & & & & & \\
\hline & $\mathbf{N}$ & $\%$ & $\mathbf{N}$ & $\%$ & & \\
\hline \multicolumn{7}{|l|}{ Usia } \\
\hline a. 20-35 tahun & 15 & 88,2 & 16 & 94,1 & 31 & 91,2 \\
\hline b. $>35$ tahun & 2 & 11,8 & 1 & 5,9 & 3 & 8,8 \\
\hline Total & 17 & 100,0 & 17 & 100,0 & 34 & 100,0 \\
\hline \multicolumn{7}{|l|}{ Pendidikan Terakhir } \\
\hline a. SD & 1 & 5,9 & 1 & 5,9 & 2 & 5,9 \\
\hline b. SMP & 1 & 5,9 & 1 & 5,9 & 2 & 5,9 \\
\hline c. SMA & 10 & 58,8 & 9 & 52,9 & 19 & 55,9 \\
\hline d. Perguruan Tinggi & 5 & 29,4 & 6 & 35,3 & 11 & 32,4 \\
\hline Total & 17 & 100,0 & 17 & 100,0 & 34 & 100,0 \\
\hline \multicolumn{7}{|l|}{ Status Pekerjaan } \\
\hline a. Bekerja & 9 & 52,9 & 7 & 41,2 & 16 & 47,1 \\
\hline b. Tidak bekerja & 8 & 47,1 & 10 & 58,8 & 18 & 52,9 \\
\hline Total & 17 & 100,0 & 17 & 100,0 & 34 & 100,0 \\
\hline
\end{tabular}

Berdasarkan tabel 1 didapatkan bahwa sebagian besar responden berada pada rentang usia 20-35 (91,2\%), sebagian besar dengan tingkat pendidikan SMA $(55,9 \%)$, dan lebih dari setengah responden bekerja $(52,9 \%)$.

\section{Tabel 2}

Rata-rata Pengeluaran ASI Sebelum (Pre-test) dan Sesudah (Post-test) Perlakuan pada Kelompok Back Massage dan Kelompok Woolwich Massage $(N=34)$

\begin{tabular}{lcccccc}
\hline Kelompok & & $\begin{array}{c}\text { Rata } \\
\text {-rata }\end{array}$ & Median & SD & Min & Max \\
\hline Back & Pre-test & 3,71 & 4,00 & 0,772 & 2 & 5 \\
\cline { 2 - 7 } Massage & Post-test & 5,71 & 6,00 & 0,686 & 4 & 7 \\
\hline Woolwich & Pre-test & 3,71 & 4,00 & 0,849 & 2 & 5 \\
\cline { 2 - 7 } Massage & Post-test & 5,06 & 5,00 & 0,827 & 4 & 7 \\
\hline
\end{tabular}

Pada tabel 2 dapat dilihat rata-rata pengeluaran ASI sebelum diberikan back massage adalah 3,71 poin dan rata-rata pengeluaran ASI sesudah diberikan back 
massage adalah 5,71 poin. Sedangkan rata-rata pengeluaran ASI sebelum diberikan woolwich massage adalah 3,71 poin dan rata-rata pengeluaran ASI sesudah diberikan woolwich massage adalah 5,06 poin.

\section{Analisis Bivariat}

\section{Tabel 3}

Perbedaan Pengeluaran ASI pada Kelompok Back Massage dan Kelompok Woolwich Massage Sesudah Dilakukan Perlakuan (Posttest)

\begin{tabular}{lcccc}
\hline \multicolumn{1}{c}{ Variabel } & N & Median & SD & p value \\
\hline Back Massage & 17 & 6,00 & 0,686 & 0,013 \\
Woolwich Massage & 17 & 5,00 & 0,827 & \\
\hline
\end{tabular}

Tabel 3 menunjukkan hasil analisis post-test menggunakan uji Mann-Whitney, didapatkan nilai median pengeluaran ASI sesudah dilakukan perlakuan pada kelompok back massage yaitu sebesar 6,00 poin sedangkan nilai median pengeluaran ASI setelah perlakuan pada kelompok woolwich massage yaitu 5,00 poin. Hasil analisis statistik diperoleh $p$ value $0,013<\alpha(0,05)$ maka disimpulkan terdapat perbedaan pengaruh yang signifikan antara back massage dan woolwich massage terhadap pengeluaran air susu ibu yang berarti Ho ditolak.

\section{Tabel 4}

Perbedaan Pengeluaran ASI Pre-test dan Post-test pada Kelompok Back Massage

\begin{tabular}{lcccc}
\hline \multicolumn{1}{c}{ Variabel } & N & Median & SD & p value \\
\hline $\begin{array}{l}\text { Nilai pengeluaran ASI } \\
\text { sebelum perlakuan }\end{array}$ & 17 & 4,00 & 0,772 & \\
$\begin{array}{l}\text { (Pre-test }) \\
\text { Nilai pengeluaran ASI } \\
\text { sesudah perlakuan }\end{array}$ & 17 & 6,00 & 0,686 & 0,000 \\
(Post-test) & & & & \\
\hline
\end{tabular}

Dari tabel 4 dapat diketahui skor perbedaan nilai median pengeluaran ASI sebelum dan sesudah dilakukan back massage adalah sebesar 2,00 poin. Hasil analisis statistik diperoleh $p$ value $0,000<\alpha(0,05)$ sehingga disimpulkan terdapat perbedaan pengeluaran ASI sebelum dan sesudah dilakukan back massage.

\section{Tabel 5}

Perbedaan Pengeluaran ASI Pre-test dan Post-test pada Kelompok Woolwich Massage

\begin{tabular}{lcccc}
\hline \multicolumn{1}{c}{ Variabel } & N & Median & SD & p value \\
\hline Nilai pengeluaran & & & & \\
ASI sebelum & 17 & 4,00 & 0,849 & \\
perlakuan (Pre-test) & & & & \\
Nilai pengeluaran & & & & \\
ASI sesudah & 17 & 5,00 & 0,000 \\
perlakuan (Post- & & & & \\
test) & & & & \\
\hline
\end{tabular}

Dari tabel 5 dapat diketahui skor perbedaan nilai median pengeluaran ASI sebelum dan sesudah dilakukan woolwich massage yaitu 1,00 poin. Hasil analisis statistik diperoleh $p$ value $0,000<\alpha(0,05)$ maka dapat disimpulkan bahwa terdapat perbedaan pengeluaran ASI sebelum dan sesudah dilakukan woolwich massage.

\section{PEMBAHASAN}

\section{Karakteristik Responden}

\section{a. Usia}

Berdasarkan hasil penelitian yang dilakukan dapat disimpulkan bahwa usia responden sebagian besar berada pada rentang usia 20-35 tahun (91,2\%). Penelitian lainnya yang dilakukan oleh Wibisono (2018) dengan 
Nur Asmita Rahma Nasution', Oswati Hasanah ${ }^{2}$, Rismadefi Woferst ${ }^{3}$, Perbedaan Pengaruh Back Massage Dan Woolwich Massage Terhadap Pengeluaran Air Susu Ibu

usia responden mayoritas berada di rentang 21-35 tahun (59\%).

Lubis (2010) mengatakan usia 20-35 tahun merupakan usia yang kemungkinan tidak mengalami risiko yang tinggi pada saat kehamilan maupun persalinan, karena pada usia tersebut organ-organ reproduksi juga berkembang secara sempurna dan memiliki kematangan yang baik termasuk organ-organ yang berperan dalam proses menyusui (Novitasari, 2015).

\section{b. Tingkat Pendidikan}

Hasil penelitian didapatkan tingkat pendidikan mayoritas berpendidikan SMA $(55,9 \%)$. Hasil penelitian ini sesuai dengan hasil penelitian Sukriana, Dewi, dan Utami (2018) mengenai masalah produksi ASI pada ibu postpartum dengan mayoritas responden $(50 \%)$ ibu postpartum berada pada tingkat pendidikan SMA.

Sutrisno (2015) mengatakan umumnya tingginya tingkat pendidikan seorang ibu mempengaruhi tingginya sikapnya dalam pemberian ASI, namun sikap adalah faktor pemicu seseorang untuk berbuat sesuatu atau tidak, tetapi sikap juga merupakan suatumproses kesadaran yang bersifat individu (Wawan, 2010)

\section{c. Status Pekerjaan}

Pada penelitian yang dilakukan pada 34 responden ibu postpartum di wilayah kerja Puskesmas Harapan Raya Pekanbaru, didapatkan hasil sebagian besar responden tidak bekerja $(52,9 \%)$. Tugas seorang ibu rumah tangga sangat banyak. Hal ini mengakibatkan kelelahan pada ibu yang memicu penurunan produksi ASI karena saat kelelahan dan stress, akan terjadi blokade dari refleks pengeluaran ASI karena adanya pelepasan dari adrenalin (epinefrin) (Soetjiningsih, 2013). Hal ini didukung pula oleh penelitian Hardiani (2017) yang menunjukkan sebanyak $73,3 \%$ responden ibu postpartum tidak bekerja.

2. Perbedaan pengaruh back massage dan woolwich massage terhadap pengeluaran ASI

Hasil analisis uji Mann-Whitney diperoleh $p$ value $0,013<\alpha(0,05)$ maka dapat disimpulkan bahwa ada perbedaan pengaruh yang signifikan antara back massage dan woolwich massage terhadap pengeluaran air susu ibu sehingga Ho ditolak.

Hasil analisis uji Wilcoxon pada kelompok back massage maupun kelompok woolwich massage diperoleh $p$ value $0,000<\alpha$ $(0,05)$ maka disimpulkan terdapat perbedaan pengeluaran ASI sebelum dan sesudah dilakukan back massage maupun woolwich massage. Hasil penelitian menunjukkan skor perbedaan nilai median sebelum dan sesudah perlakuan kelompok back massage > kelompok woolwich massage (2,00 poin), hal ini berarti back massage lebih besar pengaruhnya terhadap pengeluaran ASI daripada woolwich massage. Hal ini disebabkan karena saat dilakukan back massage, saraf pada punggung merangsang 
Jurnal Ners Indonesia, Vol. 12, No. 1, September 2021

pengeluaran endorfin di dalam tubuh yang secara tidak langsung kemudian merangsang pengeluaran hormon oksitosin yang berperan dalam pengeluaran ASI.

Pengeluaran ASI yang tidak lancar dapat menghambat proses menyusui karena tidak lancarnya pengeluaran ASI juga dapat menghambat produksi ASI. Pengeluaran ASI dan produksi ASI yang tidak lancar dan terhambat dapat dipengaruhi oleh kondisi ibu seperti ketidaknyamanan dan tidak rileks karena kondisi ini berpengaruh terhadap pengeluaran hormon oksitosin yang berperan untuk melancarkan pengeluaran ASI.

Hal ini sesuai dengan Purnomo (2016) bahwa massage dapat mengurangi ketegangan dan memberikan ketenangan pada sel saraf. Massage juga mampu membuat tubuh menjadi fit karena melatih otot dan memberikan efek relaksasi (Wong, 2012). Observasi lapangan juga membuktikan bahwa setelah dilakukannya back massage 3 hari dalam seminggu (15 menit per hari), responden merasakan rileks dan nyaman serta sebagian besar merasakan perubahan yang baik dalam pengeluaran ASI.

Saat dilakukan woolwich massage 3 hari dalam seminggu (15 menit per hari), reponden juga merasakan perubahan yang baik dalam pengeluaran ASI. Namun berbeda dengan back massage, hal ini tidak disebabkan akibat keluarnya hormon oksitosin yang berperan langsung terhadap pengeluaran ASI, akan tetapi disebabkan oleh pemberian woolwich massage yang pemijatannya dilakukan di atas gudang ASI sehingga ASI yang tertahan di dalam gudang ASI dapat keluar dan pemijatan ini dapat memperlancar aliran darah pada sistem duktus karena melemasnya jaringan.

Tidak hanya memicu pengeluaran ASI, rangsangan pada payudara juga dapat memproduksi ASI karena woolwich massage melepaskan hormon prolaktin yang berperan dalam produksi ASI untuk mempertahankan kecukupan ASI setelah dikeluarkan.

\section{SIMPULAN}

Berdasarkan penelitian diatas didapatkan bahwa responden mayoritasnya berada pada rentang usia 20-35 tahun (91,2\%). Sebagian besar dengan tingkat pendidikan SMA $(55,9 \%)$ dan bekerja yaitu sebanyak 18 responden $(52,9 \%)$.

Hasil uji statistik dengan uji Wilcoxon pada kelompok back massage maupun woolwich massage diperoleh $p$ value $0,000<\alpha$ $(0,05)$, Hal ini berarti ada perbedaan pengeluaran ASI sebelum dan sesudah dilakukan back massage maupun woolwich massage. Hasil uji statistik Mann-Whitney didapatkan hasil analisa $p$ value $=0,013<\alpha$ $(0,05)$, dapat disimpulkan ada perbedaan pengaruh yang signifikan antara back massage dan woolwich massage terhadap pengeluaran air susu ibu sehingga Ho ditolak.

Berdasarkan hasil penelitian, back massage dan woolwich massage dianjurkan 
Nur Asmita Rahma Nasution', Oswati Hasanah ${ }^{2}$, Rismadefi Woferst ${ }^{3}$, Perbedaan Pengaruh Back Massage Dan Woolwich Massage Terhadap Pengeluaran Air Susu Ibu

untuk digunakan dalam mengatasi masalah pengeluaran ASI.

\section{SARAN}

1. Bagi perkembangan Ilmu Keperawatan

Hasil penelitian ini diharapkan bisa menjadikan back massage dan woolwich massage sebagai evidence based practice serta menjadi salah satu intervensi non farmakologis yang dapat melancarkan pengeluaran ASI.

2. Bagi tempat penelitian

Hasil penelitian diharapkan memberikan konstribusi dalam meningkatkan kualitas pelayanan kesehatan bagi Puskesmas Harapan Raya Pekanbaru dalam melancarkan pengeluaran ASI.

3. Bagi masyarakat

Hasil penelitian diharapkan dapat dijadikan terapi yang mudah, efektif dan efisien serta mudah dilakukan di rumah dalam melancarkan pengeluaran ASI khususnya untuk ibu yang pengeluaran ASI-nya tidak lancar.

\section{DAFTAR PUSTAKA}

Barokah, L., \& Faradila, U. (2017). Pengaruh Pijat Woolwich terhadap Produksi ASI di BPM Appi Amelia Bibis Kasihan Bantul. Diperoleh tanggal 29 November 2018 dari http://jurnal.lppm.unsoed.ac.id/ojs/index.p $\mathrm{hp} /$ Prosiding/article/view/427/352

Cunningham, F.G. (2016). Williams Obstetrics (Edisi Bahasa Indonesia). Jakarta: EGC

Dewi, A.P.S. (2016). Efek Pijat Punggung terhadap Produksi ASI pada Ibu Pasca Bedah Sesar di RSUD Kebumen. Jurnal
Program Studi Ilmu Kebidanan Program Magister (S-2) STIKES 'AISYIYAH Yogyakarta. Diperoleh tanggal 5 Januari 2019 dari http://digilib.unisayogya.ac.id/1864/1/Nas kah\%20PUBLIKASI.pdf

Dharma, K.K. (2015). Metodologi Penelitian Keperawatan (Edisi Revisi). Jakarta: TIM

Hardiani, R.S. (2017). Status paritas dan pekerjaan ibu terhadap pengeluaran asi pada ibu menyusui 0-6 bulan. Diperoleh pada tanggal 19 April 2019 dari https://repository.unej.ac.id/handle/12345 6789/81185

Hidayati, Y. (2017). Hubungan usia dan jenis persalinan dengan kejadian postpartum blues pada ibu post partum di wilayah puskesmas jetis ii kabupaten bantul. Diperoleh pada tanggal 17 April 2019 dari http://digilib.unisayogya.ac.id/2554/1/NA SKAH\%20PUBLIKASI.pdf

Indiarti, M.T. (2015). Panduan terbaik kehamilan, persalinan, dan perawatan bayi. Yogyakarta: Indoliterasi

Isnaini, N., \& Diyanti, R. (2015). Hubungan Pijat Oksitosin pada Ibu Nifas terhadap Pengeluaran Asi di Wilayah Kerja Puskesmas Raja Basa Indah Bandar Lampung Tahun 2015. Diperoleh tanggal 7 Januari 2019 dari http://jurnal.lppm.unsoed.ac.id/ojs/index.p hp/Prosiding/article/view/427/352

Khasanah, N. (2011). Asi atau Susu Formula Ya?. Yogyakarta: Flashbooks

Kementrian Kesehatan Republik Indonesia. (2018). Profil Kesehatan Indonesia 2017. Diperoleh tanggal 30 Desember 2018 dari http://www.depkes.go.id/resources/downl oad/pusdatin/profil-kesehatanindonesia/Profil-Kesehatan-Indonesiatahun-2017.pdf

Lubis, L. N. (2009). Depresi tinjauan psikologis, Edisi 1. Jakarta: Kencana

Novitasari, H. (2015). Hubungan Umur Ibu Dengan Onset Laktasi Pada Ibu Postpartum di Rumah Sakit Pku Muhammadiyah Yogyakarta. Diperoleh pada tanggal 17 April 2019 dari http://digilib.unisayogya.ac.id/528/1/Naskah\% 20Publikasi\%20HEPY\%20NOVITASARI\% 2 0\%28201410104053\%29.pdf 
Nurhanifah, F. (2013). Differentiation Between the Effectiveness of Back Massage and Lukewarm Breast Compress in The Increasing of Breast Milk Production. Diperoleh pada tanggal 19 April 2019 dari http://ejournal.umm.ac.id/index.php/keper awatan/article/view/2359/3196

Pamuji., S.E.B., Supriyana., Sri, R., \& Suhartono. (2014). Pengaruh Kombinasi Pijat Woolwich dan Endorphine Terhadap Kadar Hormon Prolaktin dan Volume ASI (Studi Pada Ibu Postpartum di Griya Hamil Sehat Majesem Kabupaten Tegal). Diperoleh tanggal 5 Januari 2019 dari https://www.google.co.id/url?sa=t\&rct=j\& $\mathrm{q}=\&$ esrc $=\mathrm{s} \&$ source $=$ web $\& \mathrm{~cd}=6 \& \mathrm{ved}=2 \mathrm{ah}$ UKEwiVz8jrvq7gAhUSU30KHXbIDa0Q FjAFegQIBRAC\&url=http $\% 3 \mathrm{~A} \% 2 \mathrm{~F} \% 2 \mathrm{~F}$ ojs.stikesbhamadaslawi.ac.id\%2Findex.ph p\%2Fjik\%2Farticle\%2Fdownload\%2F91 $\% 2 \mathrm{~F} 87 \% 2 \mathrm{~F} \&$ usg=AOvVaw2fpbsaxFJq6R jcDrlXHJHl

Peraturan Pemerintah RI Nomor 33. (2012). Pemberian asi eksklusif. Diperoleh tanggal 4 januari 2019 dari http://pergizi,org/images/stories/download s/PP/pp\%2033\%202012\%20

ttg\%20pemberian\%20asi\%20eksklusif.pdf

Purnomo, A.M.I. (2016). Manfaat Swedish Massage Untuk Pemulihan Kelelahan pada Atlet. Diperoleh tanggal 20 April 2019 dari

http://ojs.unpkediri.ac.id/index.php/efekto r-e/article/view/200/120

Safitri,W.N., Susilaningsih., \& Panggayuh, A. (2015). Pijat Punggung dan Percepatan Pengeluaran ASI pada Ibu Postpartum. Jurnal Poltekes Kemenkes Malang. Diperoleh tanggal 3 Januari 2019 dari http://jurnal.poltekkes-

malang.ac.id/berkas/2f10-148-153.pdf

Sherwood, L. (2012). Fisiologi Manusia: dari Sel ke Sistem (Edisi Bahasa Indonesia). Jakarta: EGC

Soenarwo, B.M. (2012). 360 Pekan Masa Keemasan Anak; Sekali Seumur Hidup. Jakarta: AMP Press
Soetjiningsih. (2013). Asi: Petunjuk untuk tenaga kesehatan. Jakarta: EGC

Suherni, W.H. (2009). Perawatan masa nifas (Cetakan Ketiga). Yogyakarta: Fitramaya

Sukriana., Dewi, Y.I., \& Utami, S. (2018). Efektivitas pijat woolwich terhadap produksi asi post partum di Puskesmas Payung Sekaki Pekanbaru. Diperoleh tanggal 28 November 2018 dari https://jom.unri.ac.id/index.php/JOMPSIK /article/viewFile/21286/20595

Sutrisno. (2015). Hubungan tingkat pendidikan ibu dengan sikap pemberian asi eksklusif di wilayah puskesmas kartasura kabupaten sukoharjo. Diperoleh pada tanggal 19 April 2019 dari http://eprints.ums.ac.id/39485/12/NASKA H\%20PUBLIKASI.pdf

Wahyuni, I.D., Hasanah, O., \& Dewi, W.N. (2018). Pengaruh swedish back massage terhadap pengeluaran air susu ibu. Jurnal Online Mahasiswa (JOM) Universitas Riau. Diperoleh tanggal 29 Januari 2019 dari https://jom.unri.ac.id/index.php/JOMPSIK /article/viewFile/21339/20648

Ward, J., Clarke, R., \& Linden, R. (2009). At a Glance Fisiologi. Jakarta: Erlangga

Wawan, A.D. (2010). Teori dan pengukuran pengetahuan, sikap, dan perilaku manusia. Yogyakarta: Nuh Medika

Wibisono, A. (2018). Hubungan Karakteristik Personal dengan Kecemasan pada Ibu Postpartum di Wilayah Kerja Puskesmas Gatak Sukoharjo. Diperoleh pada tanggal 17 April 20192 dari http://eprints.ums.ac.id/59383/25/NASPUB\% 20PERPUS\%202.pdf

Wong, F. (2012). Panduan Lengkap Pijat. Jakarta: Penebar Plus

Yuliarti, N. (2010). Keajaiban asi makanan terbaik untuk kesehatan, kecerdasan, dan kelincahan si kecil. Yogyakarta: ANDI 